\title{
Investigating the Existing of Environmental Management Accounting for Better Environment Management: A Case Study in a University
}

\author{
Lyna Latifah Kardiyem Nurdian Susilowati \\ Department of Economics Education, Faculty of Economics, Universitas Negeri Semarang, Indonesia
}

\begin{abstract}
This paper aims at investigating the existence of EMA in University and the role it plays in improving environmental performance. The current research is a case study conducted in State University of Semarang. The data are collected through in-depth interview. Furthermore, the data are validated using triangulation technique by cross-checking them against the available data such as SOP, budget and strategic plan. The result finds that State University of Semarang has implemented EMA well. Their accounting recording is even done based on the existing activities. There are only few EMA-related studies in College setting. This research gives some contibrution by providing information particularly regarding the implementation of EMA in University, how EMA can be used to manage environmental costs and it can also be used to prepare strategies to improve environmental performance.
\end{abstract}

Keywords: Environmental management accounting, managing environmental cost, university

DOI: $10.7176 / \mathrm{EJBM} / 11-8-06$

Publication date:March $31^{\text {st }} 2019$

\section{Introduction}

Several tens of years ago, we still found it hard to find literature related to environmental accounting. However, for the last few years the number of studies on environmental accounting has been growing fast and significantly (Gray \& Bebington,). The growth comes from the pressure that stakeholders impose who are concerned about the impacts that organizations' activities have on their environment (Burit et al, 2002 and IFAC, 2005). These stakeholders include internal stakeholders such as employees who are affected by pollution at work and external stakeholders such as the society, environmental activist group, regulations and law, investors, customers, suppliers who are also affected by pollution. Accounting is now facing challenges, not just through its role of recording and reporting about finance but also through the way the environment is managed (Hopwood, 2009; Schaltegger and Wagner, 2006). Environmental Management Accounting (EMA) is attractive since it is acknowledged for being able to be used as a management tool in assisting financial performance improvement through environmental accountability improvement.

There are 2 versions of EMA definitions (Burrit dkk,2002). The first approach states that EMA is represented as an internal environmental accounting employing monetary measurements (Schaltegger and Burrit, 2000). The second one suggests that EMA relates to monetary and non-monetary in internal accounting (Bennet and James 1997, ECOMAC, 1996,IFAC 2005). The definition of EMA according to IFAC itself is environmental management and economic performance through the development and implementation of accounting system and practice related to environment. Unlike any other reporting and auditing in various companies, environmental management accounting includes life cycle, full cost accounting, benefit assessment and strategic plan for environment management. Finally, the definition of EMA according to Economic \& Social Affair (UNITED NATIONS,2001) is a process of identifying, collecting, estimating, analyzing, internally reporting and using physical information flow (such as materials, water, and energy flow), environmental cost information and other monetary information related to environmental decision-making in an organization.

Many have conducted EMA-related studies in industry setting. However, only a view studies have been conducted on EMA in education setting. While it is true that as an entity providing service in education field University produces fewer impact on the environment as compared to manufacturing industry, it remains a fact that it produces some impact either directly or indirectly (Bennet et al, 2006; Chang, 2013). The indirect impact includes the change in attitude towards the environment in their educational and research activities and the direct ones involves consumption of resources such as paper, water, electricity and production of other solid wastes.

One of EMA-related studies in University setting is conducted by Chang (2013) who researches environmental management cost issue through accounting perspective. The research is conducted through a case study in three universities in Taiwan. The results show that EMA has not been employed to manage the environmental costs in these three universities in Taiwan. Another research by Sutherland et al (2008) investigates the possibility of introducing EMA in Canterbury University, New Zealand. Its results indicate that EMA has been implemented in Canterbury University despite it being small-sclae. Some aspects of environmental performance such as electricity consumption, waste management, fuel consumption is recorded.

This study aims at investigating the existence of EMA in university and the role it plays in improving 
environmental performance. EMA is firstly developed in business sector. However, the number of effort made to export its implementation to the field of services, university in particular, is highly limited. It is expected that this research could give some contibution of empirical illustration of EMA practice in university and how this EMA can be used as a tool to improve environmental performance.

\section{Literature Review}

Legitimacy theory can explain the relationship between university and general public around it. University consumes natural resources in its process of providing services to its students and the general public give grants to universities a "right" to operate based on its legitimacy. This consumption of resources undoubtedly has a potential of affecting the environment. When the manager implement EMA system, it will serve as a way of showing legitimacy of their operation and managing the general public. If the stakeholders with their power are concerned about the impact the university has caused on the environment, the university will eventually apply EMA system and manage their environmental performance, hence they can show the legitimacy of their operation. The society as one of these stakeholders are actually concerned about the quality of learning, research results as well as about environmental performance of the university (Chang, 2007).

\section{EMA}

Environmental management accounting is a way of counting material use and environmental costs in one's business activities. Material accounting is tracing the material flow through a facility to calculate the input and output, aiming at evaluating the resources use and for improvement. Meanwhile, environmental cost accounting is identification and allocation of material flow or other physical aspects (IFAC (2005); Graff et al. 1998).

Environmental management accounting is also defined as environment management and economic performance through the development and implementation of environment management, both its accounting system and practices (IFAC, 2005). Meanwhile, according UNDSD, Environmental management accounting provides a mechanism of identifying and measuring all spectrums of environmental costs in production process and economic benefits in preventing pollution, and integration of costs and benefits in daily business decisionmaking.

According to Jasch (2002), Environmental Management Accounting is a combined approach of providing data transition from financial accounting, cost accounting and mass balances to improve material efficiency, reduce environmental impact and reduce cost of environmental protection. The central focus of environmental management accounting, according to UN DSD is the total expenditure assessment of environmental costs in dealing with emission, disposal, maintenance and management of environment.

Bennet and James (1997, p 34) identify 6 areas related to environmental management accounting namely:

1. Identifying cost reduction and improvement

2. Prioritizing environment-related activities

3. Determining product costs, mix and development decisions

4. Increasing customer value

5. Future-proofing investment and other decisions with long term consequences

6. Assessing the eco-efficiency and/or sustainability of a company's activities.

\section{Research Method}

This is a qualitative research using a case study for it is thought to be more flexible in helping researchers find the important factors which cannot be covered as well issues arising from a real-life context which cannot be manipulated directly (Herriott \& Firestone 1983; Yin 2003b). The case study is conducted in State University of Semarang. The researcher chooses State University of Semarang since this university is highly concerned about reserving the environment. State University of Semarang is a state university located in Central Java, Indonesia.

The data are collected through in-depth interview, observation and documents. The interview is made with those holding important positions and well-aware of environment management in the university such as the university's budgeting department chief, the university's Conservation Board department Chief, Financial Department in Conservation Board, staff at conservation board, vice dean, and lecturers. The given questions are semi-structured. This research is also addressed to answer the following questions:

1. How are the funding and management in relation to environment in the university?

2. To what extent the environmental costs recording in the university is?

3. How is EMA implemented in the university?

4. How is the environmental performance in the university and how is it measured?

Documentation is also done to make a cross-check against several budgeting-related documents, strategic plan and financial data. Observation and documentation is used to match the interview output, so that it can be used to test its validity.

The data are analyzed using naturalistic approach (Tomkins \& Groves, 1983) through some stages : 1) exploration 
is used to dig up the respondents' experiences and opinions in regard to EMA in the university, 2) inspection is used to obtain an deeper understanding of EMA in the university more flexibly, 3) transcription is transcribing the data resulting from the interview and re-read as a whole 4) deciding by reducing the unnecessary data 5) transformation is discussing the meaning of each unit into sensitive expressions regarding EMA

\section{Results and Discussion}

\subsection{Description of research object}

The case study in this research is conducted in State University of Semarang, which is one of state universities in Semarang, Central Java province, Indonesia. Unnes has declared itself a Conservation University on March 12, 2010. The principles of protecting, reserving and utilizing natural resources more wisely, arts and culture reservation, and the implementation of University's Tri Dharma (Three Principles) with eco-friendly insight are those principles it is about to implement. In its effort of implementing it, a conservation team is formed and then tasked to design and create blue print to prepare UNNES as a Conservation University. This conservation team is specifically tasked to develop some policies and activities related to biodiversity, green architecture and campus internal transportation governance, waste management, clean energy, paperless policy, arts and culture conservation, as well as conservation cadre handling.

UNNES's position as a conservation university is confirmed even further by the issuance of Ministerial Regulation of National Education of the Republic of Indonesia Number 8 year 2011 concerning Statute of State University of Semarang, wherein it is stated that UNNES's vision is to be a worldclass-level, healthy, superior and prosperous conservation university in 2020. In 2011, this conservation team was turned into Conservation University Development Body under the Decision Letter of UNNES Rector Number 35/P/2011. In 2016, the Conservation Development Body was further changed into Conservation Development Technical Executing Unit (UPT).

\subsection{Environment-related funding and fund management in the University}

State University of Semarang pays undivided attention to environment and its conservation. This fact can be seen from the existence of specific body it establishes to manage conservation and environment, namely Conservation Development Technical Executing Unit. This body is assigned the responsibility to manage the fund for various activities such as biodiversity, green architecture, waste management, clean energy, paperless policy, arts and culture conservation as well as conservation cadre handling.

The funding to finance environment-related activities in UNNES comes from the pre-budgeted fund. As for the amount, it depends on the budget proposed by Conservation Development Technical Executing Unit by submitting the program proposal along with its costs. Furthermore, upon this proposal submission, the amount will be alloted, depending on the decision made by Organisasi Tata Kelola/Governance Organization (OTK). The budget preparation itself involves many parties such as, members of Conservation Technical Executing Unit, leaders in this case Vice Rector IV, and the University's budget department. The budgeting process has employed a certain system, namely SIANGGAR (budget system).

One of the budgets in one environmental activity in UNNES can be illustrated as follows:

Total Budget for Program Daur Ulang dan Pengomposan Menuju UNNES Zero/Minimum Waste or Recycling and Composting for Zero/Minimum Waste UNNES Program amounting to Rp121,540,000.- with the detail of each activity as follows:

\begin{tabular}{|c|c|c|}
\hline $\begin{array}{l}\mathbf{N} \\
\mathbf{0}\end{array}$ & Activity & Budget \\
\hline $\mathbf{a}$ & UNNES Waste Management Blue Print Workshop & $4,750,000$ \\
\hline b & UNNES Waste Management Blue Print Drafting & $1,140,000$ \\
\hline c & UNNES Waste Management Blue Print Finalization & $7,140,000$ \\
\hline d & UNNES Waste Management Roadmap \& Framework FGD & $10,625,000$ \\
\hline e & UNNES Waste Management Roadmap \& Framework Drafting & $1,190,000$ \\
\hline f & UNNES Waste Management Roadmap \& Framework Finalization & $7,140,000$ \\
\hline g & UNNES Waste Bank Management FGD & $10,625,000$ \\
\hline h & UNNES Waste Bank Management Manual Drafting & $7,090,000$ \\
\hline i & UNNES Waste Bank Management Manual Finalization & $7,090,000$ \\
\hline j & UNNES Waste Bank Management IT Development Workshop (Internal Speaker) & $4,750,000$ \\
\hline $\mathbf{k}$ & $\begin{array}{l}\text { Implementation of Paper Waste Handling Processing into Handmade Paper } \\
\text { (Procurement and Maintenance) }\end{array}$ & $15,000,000$ \\
\hline $\mathbf{l}$ & $\begin{array}{l}\text { Construction of Inorganic Waste Processing Building and its Facilities and } \\
\text { Infrastructure (Procurement and Maintenance) }\end{array}$ & $45,000,000$ \\
\hline
\end{tabular}




\subsection{Environmental Costs Recording in the University}

Environmental costs consist of internal and external costs related to all costs spent for environmental protection and damages (VDI, 2000). The environmental protection cost includes prevention, disposal, planning, controlling, action costs to prevent damages from occuring to the environment around the university. The costs spent for environment protection and remidy can be classified into:

1. Prevention Cost: this prevention cost includes the cost to prepare energy governance management blue print document, waste bank management blue print draft, water conservation blue print draft and UNNES Campus Environmental Management Identification Result Document Drafting

2. Costs related to waste management and energy management: these costs concerns with the expenditure for paper waste handling, solar cell procurement and maintenance costs, organic waste processing cost, electricity energy management procurement and maintenance costs

3. Costs related to conservation resources: the costs spent for water conservation, tree planting costs, butterfly house procurement, campus's seed garden procurement and maintenance

4. Conservation Pillar Integration Costs in the Administration of UNNES Education, Research, and Public Service: the costs related to integration of conservation into education, research and public service, the costs related to procurement of Indonesian Journal of Conservation, Website Development and EBSCO Indexation for Indonesian Journal of Conservation

The costs spent by the university for environmental costs are made to support 4 big activities around which the work plan in the relevant year revolves. These activities include:

1) State University of Semarang's Conservation Development Technical Executing Unit Governance Reinforcement Activity

2) State University of Semarang's Conservation Pillar Implementation Reinforcement Activity

3) Reinforcement of Conservation Integration into State University of Semarang's Tri Dharma (The Three Principles)

4) Routine Activities

\subsection{EMA Implementation in the University}

The accounting recording in UNNES has employed an integrated system, namely SIKEU. This financial information system enables the accountants to perform the accounting recording according to the pre-planned budget. The costs spent are inputted into the system and the transaction receipts are attached. The existing accounts are matched against the MAK already included in the system. UNNES has not specifically implemented environmental management accounting. The decisions made in regard to environment are based on the budget and financial accounting according to SIANGGAR (a system for budget) and SIKEU (a system for financial accounting).

\subsection{Environmental performance in the University and its Measurement}

State University of Semarang uses UI green metric as a reference for performance assessment. In 2016, UNNES sits in the 6th place in UI green metric. Below is the data on UI green metric ranking for 2016:

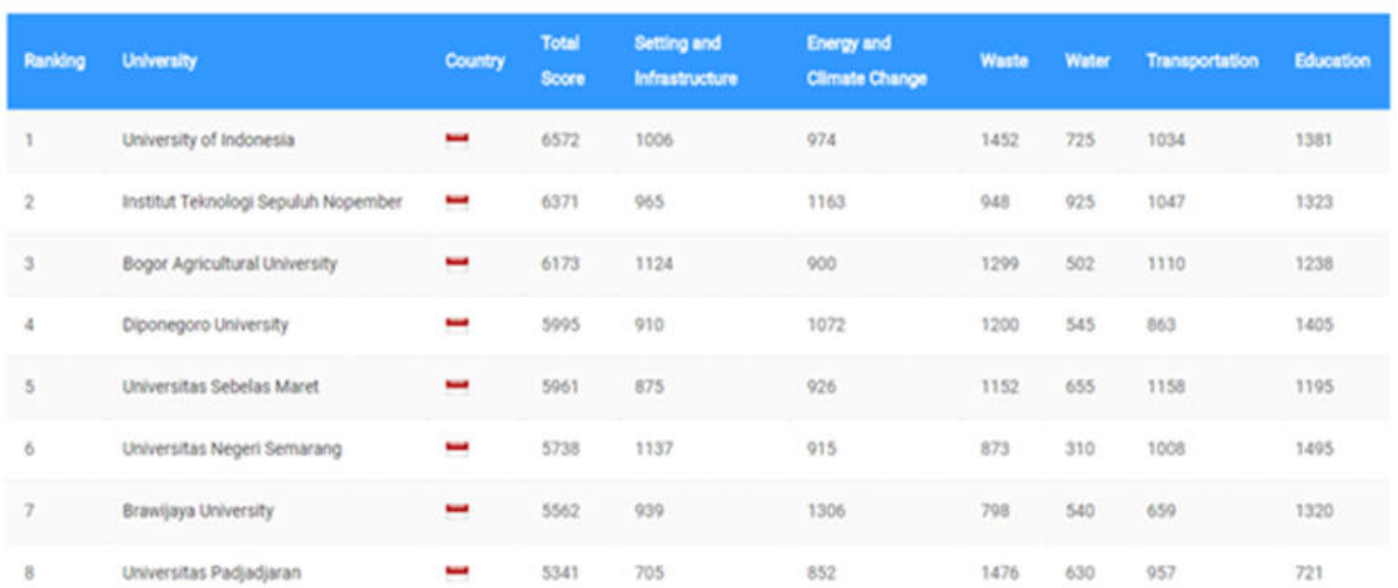

Source: UI Green Metric

Based on the guideline from UI green metric, there are 6 assessment categories, namely Setting and Infrastructure with score weight $15 \%$, energy and climate change $21 \%$, waste $18 \%$, water $10 \%$, transportation $18 \%$, and education $18 \%$. Each category is assessed based on some indicators. The indicators of Setting and 
Infrastructure include: campus setting, type of college institution, number of campus sites, total campus area (m2), total main ground floor area of building (m2), total main campus building area (m2), total parking area $(\mathrm{m} 2)$, total area on campus covered in vegetation in the form of forest ( $\%)$, total area on campus covered in planted vegetation $(\%)$, total area on campus for water absorption beside forest planted vegetation (\%), total number of student, total number of academic and administrative staff, university budget for sustainability effort within a year. Energy and climate change is assessed through such indicators as: energy-efficient appliances usage, smart building implementation, renewable energy produce inside campus, electricity usage per year, ratio of renewable energy produce/production toward total energy usage per year, elements of green building implementation as reflected in all construction and renovation policy, greenhouse gas emission reduction program, total carbon footprint (co2 emission). Waste is assessed through such indicators as: Program to reduce paper and plastic uses in campus, university waste recycling program, toxic waste treatment, inorganic waste treatment, organic waste treatment, sewerage disposal. The indicators used in assessing water category include: water conservation program implementation, water recycling program implementation, the use of water-efficient appliances, treated water consumed. Transportation is assessed by the following indicators: number of cars owned by your university, number of cars entering the university daily, number of motorcycles entering the university daily, number of campus bus operated in university, average passengers of each campus shuttle bus, total trips for campus bus service each day, number of bicycles that are found on campus on an average day, parking area type, parking area reduction for private vehicles within 3 years, initiatives to decrease private vehicles on campus, campus shuttle service, bicycle and pedestrian policy on campus, the approximate travel distance of a vehicle each day inside campus only. Education is assessed by such indicators as: number of courses related to environment and sustainability, total number of courses offered, total research fund dedicated to environmental and sustainability research, total research fund, number of scholarly publication on environment and sustainability published, number of scholarly event related to environment and sustainability, existence of university-run sustainability website (UI greenmetric, 2016).

\section{Conclusion}

The funding in UNNES is budgeted based on the need of UPT Bangvasi, which is tasked to manage the fund related to environment in the university. The budgeting procedure complies with the SOP and uses a budget system (Sianggar). The recording of environmental costs has been done according to the existing activities/programs and they are recorded in the University's accounting system (Sikeu). The financial recording is integrated into the master system in the university. UNNES has not specifically implemented environmental management accounting. The decisions made in regard to environment are based on the budget and financial accounting according to SIANGGAR (a system for budget) and SIKEU (a system for financial accounting). State University of Semarang uses UI green metric to assess their performance assessment. They reached an achievement in 2016, that is UNNES sits in the 6th place by country in UI green metric. This finding gives some contribution for institution, particularly college in implementing EMA. In addition, this research also seek to add the literature related to EMA in college which is still rarely conducted. However, this research has its own limitations including, it is a qualitative research, thus it cannot be generalized, this research only portrays environmental activities and EMA in university's environment thus more EMA innovations are needed to be applied to universities.

\section{Refferences}

Bennett, M., Hopkinson, P. and James, P. (2006), "Benchmarking environmental performance in the English university sector: the experience of the higher education environmental performance improvement (HEEPI) project”, in Schaltegger, S., Bennett, M. and Burritt, R. (Eds), Sustainability Accounting and Reporting, Springer, Dordrecht, pp. 409-30.

Bennett, M. and James, P. (1997), "Environment related management accounting: current practice and future trends", Greener Management International, Vol. 17, pp. 33-51.

Burritt, R., Hahn, T. and Schaltegger, S. (2002a), "Towards a comprehensive framework for environmental management accounting: links between business actors and environmental management accounting tools", Australian Accounting Review, Vol. 12 No. 2, pp. 39-50.

Chang, H. C. (2007). Environmental management accounting within universities: current state and future potential.

Chang, Huei-Chun (2013) "Environmental management accounting in the Taiwanese higher education sector: Issues and opportunities", International Journal of Sustainability in Higher Education, Vol. 14 Issue: 2, pp.133-145, doi: 10.1108/14676371311312851

ECOMAC, (1996), Synreport: Eco-Management Accounting as a Tool of Environmental Management (the Ecomac project), IEM Small Business Reseach and Consultancy. http: //www.eim.nl/uk/nl/ecomac.html.

Graff, R.G., Reiskin, E.D., White, A.L. and Bidwell, K. (1998), Snapshots of Environmental Cost Accounting, Tellus Institute, Boston, MA.

Gray,R, J Bebbington 2000- Environmental accounting, managerialism and sustainability: Is the planet safe in the 
hands of business and accounting?Advances in environmental accounting \& management,vol 1.pp 1-44

Herriott, R.E. and Firestone, W.A. (1983) Multisite Qualitative Research: Optimizing Description and Generalizability. Education Researcher, 12, 14-19.

Hopwood, A.G. (2009), “Accounting and the environment”, Accounting, Organizations and Society, Vol. 34 Nos 3/4, pp. 433-9.

IFAC (2005), International Guidance Document: Environmental Management Accounting, International Federation of Accountants, New York, NY

Schaltegger, S. and Wagner, M. (Eds) (2006), Managing the Business Case for Sustainability, Greenleaf Publishing Limited, Sheffield.

Jasch, C. (2002), Austrian Pilot Projects on Environmental Management Accounting and Further Integration with ECODESIGN, available at: www.un.org/esa/sustdev/sdissues/technology/fdzemaforlundmeeting.pdf

Schaltegger, S. and Burritt, R. (2000), Contemporary Environmental Accounting, Greenleaf Publishing, Sheffield.

Tomkins Cyril and Roger Groves1983, The everyday accountant and researching his reality Accounting, Organizations and Society, vol. 8, issue 4, 361-374

UNDSD (2001), Environmental Management Accounting: Procedures and Principles, United Nations Division for Sustainable Development, New York, NY.

Yin, Robert K. 2013. Case Study Research: Design and Methods, SAGE Publications. 